\title{
OPEN The effect of water level in vertical aquaculture systems on production performance, biochemistry, hematology, and histology of Anguilla bicolor bicolor
}

\author{
Eko Harianto $^{1,2}$, Eddy Supriyono ${ }^{3 凶}$, Tatag Budiardi $^{3,5}$, Ridwan Affandi $^{4,5}$ \& \\ Yani Hadiroseyani ${ }^{3,5}$
}

The water level in the cultivation of eel (Anguilla bicolor bicolor) is an important study in order to provide the optimal water level for cultivation. Optimizing the water level will affect the substitution of respiration energy with energy to grow. In addition, the water level information is related to the efficiency of water use for eel production in the future. Information on water level for eel production is still very limited, so this research is necessary to do. A total of 120 eel elver (initial weight $13.66 \pm 0.09 \mathrm{~g}$ ) were collected from eel companies in Bogor City, Indonesia. Fish were reared in vertical aquaculture systems with a stocking density of 10 fish per container for 60 days. The artificial feed containing $55 \%$ protein given as much as $3-5 \%$ of the biomass. Absorption and water replacement were done $20 \%$ per day. The result of this research showed that fish weight increased with an average of $33.45 \pm 0.33 \mathrm{~g}$. Different water levels had an impact to KKb, SGOT, ALP, and He. There was erosion of the skin epidermis and necrosis of the gill filaments due to the adaptation process. Water quality was within the optimum range for all treatments and $1.5 \mathrm{~cm}$ water level is recommended for maintenance (SGOT, ALP and He values were closest to normal values).

Anguilla spp. eel is a catadromous fish that lives in two habitats, namely marine waters during the larval stage and inland waters (brackish and fresh) during the juvenile to adult stage $\mathrm{e}^{1,2}$. A total of 19 eel species exist in tropical and sub-tropical waters ${ }^{3}$. Thirteen species inhabit tropical and six species are in subtropical waters. One type of tropical eels is Anguilla bicolor bicolor which is found on the west coast of Sumatra Island and the south coast of Java Island ${ }^{4,5}$ As with eels in general, A. bicolor bicolor eels also carry out migration in their life cycle. During this migration phase, eels are sometimes encounter extreme water condition such as changes in water levels ${ }^{1}$. This occurs when eels migrate upstream (fresh water) through limited water and semi-dry rivers ${ }^{6}$. This condition requires eels to adapt to water level changes. The study of the migration physiology of eels has been reported, especially for captured eels which have been analyzed for their physiological responses ${ }^{7-9}$.

In contrast to cultivated eels, slight information is available regarding the evaluation of water levels for the aquaculture process. This is because the use of volume and water depth is still high in the cultivation process. The breeding and rearing process of laboratory-scale eels with a regular aquarium using water depth and volume ranged from 20 to $35 \mathrm{~cm}^{10-13}$. Meanwhile, for the production scale with pond, the water level commonly used is between 50 and $200 \mathrm{~cm}^{14-16}$. The water level in eel fish farming will have a direct impact on physiological responses, growth and survival. The water level will determine the amount of energy used by the fish to absorb oxygen at the surface and reduce the energy utilization for growth. The Anguilla anguilla eels spend a lot of energy in vertical migration so their acceleration is slower and the distance covered is shorter ${ }^{17}$. During the

\footnotetext{
${ }^{1}$ Doctoral Program Student, Graduate School, Department of Aquaculture, Faculty of Fisheries and Marine Sciences, IPB University, Jalan Agatis, IPB Dramaga, Bogor 16680, Indonesia. 2Aquaculture Study Program, Faculty of Agriculture, Jambi Batanghari University, Jl. Slamet Ryadi, Broni Jambi 36122, Indonesia. ${ }^{3}$ Department of Aquaculture, Faculty of Fisheries and Marine Sciences, IPB University, Jalan Agatis, IPB Dramaga, Bogor 16680, Indonesia. ${ }^{4}$ Department of Aquatic Resources Management, Faculty of Fisheries and Marine Sciences, IPB University, Jalan Agatis, IPB Dramaga, Bogor 16680, Indonesia. ${ }^{5}$ These authors contributed equally: Tatag Budiardi, Ridwan Affandi and Yani Hadiroseyani. ${ }^{凶}$ email: eddysupriyonoiipb@gmail.com
} 
cultivation process, if the dissolved oxygen in the rearing container $<1 \mathrm{mg} \mathrm{L}^{-1}$, the eels will swim to the surface of the water, the position of the body is in direct contact with free air and the head is hidden out of the water with the gill cavities that swell to resemble a vertical pipe ${ }^{18,19}$. This swimming behavior will last a long time and cause the fish to run out of energy which can lead to death so that specific information is needed regarding the optimal water level for eel cultivation.

Optimizing water use is related to efficiency. The low water level with a small volume will result in high water use efficiency in producing fish biomass. Eel elver A. bicolor bicolor stadia are able to live and grow at a water level of $1.5 \mathrm{~cm}$ or as high as its body, but the results of this study still showed low production performance ${ }^{20}$. The growth of $A$. bicolor bicolor eel increased with the reduction of water volume ${ }^{21,22}$. In addition, eel farming commonly still employs horizontal land, so that the efficiency of land usage is still low. The vertical cultivation is a system that makes use of land vertically. This system has been widely developed for crop production ${ }^{23-26}$ and some aquatic organisms such as the spiny lobster Jasus edwardsii ${ }^{27}$ and mud $\mathrm{crab}^{28}$. Information on the vertical eel cultivation system has not been extensively reported thus it is a great opportunity to improve this system in the context of efficient water and land utilization for eel cultivation in the future. This study aims to evaluate the effect of water level on the maintenance of eel elver A. bicolor bicolor with vertical aquaculture system (VAS) on physiological conditions and production performance.

\section{Material and methods}

This research was conducted from June to August 2019 at the Laboratory of Production Technology and Aquaculture Management, Aquaculture department, Faculty of Fisheries and Marine Science, IPB University. The analysis of blood biochemistry was carried out at the animal teaching hospital, Faculty of Veterinary Medicine, IPB University. The analysis of hematology, histology, and water quality was conducted in a laboratory within the Aquaculture department, Faculty of Fisheries and Marine Science, IPB University. This study has met the guidelines and protocols approved by the Animal Ethics Committee of IPB University. This research was also accompanied by the staff of the Ethics Committee for the stages of using test animals, anesthetizing test animals, and taking blood samples. The authors of this research complied with the ARRIVE guidelines.

Experimental animals and container set up. The eel elver in this study (average weight $13.66 \pm 0.09 \mathrm{~g}$ ) is a fish cultivated from an eel company in Bogor City, West Java, Indonesia. A total of 120 fish were stocked into 12 rearing containers $(68 \mathrm{~cm} \times 47 \mathrm{~cm} \times 39 \mathrm{~cm})$, arranged vertically $\left(10\right.$ fish per container $\left.{ }^{19}\right)$, and reared for 60 days. The experiments were divided into four groups. Among the twelve units of eel rearing containers, different water levels were given for each of the three rearing containers which included a water level of $1.5 \mathrm{~cm}(\mathrm{~A}), 2.25 \mathrm{~cm}(\mathrm{~B}), 3.0 \mathrm{~cm}$ (C) and $3.75 \mathrm{~cm}$ (D). The vertical aquaculture system constructed for rearing the experimental fish was designed by arranging three cultivation tubs vertically like a drawer with wooden support frames, each was equipped with a recirculation system (Fig. 1). The maintenance container measuring $68 \mathrm{~cm} \times 47 \mathrm{~cm} \times 39 \mathrm{~cm}$, each of which was supplied with supporting components such as a top filter containing synthetic cotton, activated carbon and zeolite, a $13-\mathrm{W}$ water pump with a total discharge of $0.07 \mathrm{~L} \mathrm{~s}^{-1}$ and aeration that functioned to supply oxygen as well as shelter for the test fish made of raffia strings. The water reservoir in this experiment was only used in the water change process. The water from reservoir was flowed through a 0.5 -in. PVC pipe to the cultivation tubs. The water flow that entered the maintenance container was adjusted by using a water tap according to the percentage of water change. Water from the maintenance tubs came out through the outlet channel in the form of a $1 \mathrm{~cm}$ aeration hose located on the bottom wall of the tub. This outlet channel functioned to control the water level during the water change process. The water then was streamed into a temporary storage tank by gravity which is then flowed back to the reservoir using a pump.

Feed and water preparation. During the experimental process, the fish were fed three times a day with limited feed amount of 3-5\% from the biomass in each rearing container. The type of feed given was commercial powder (PIS 1-Japfa PT Suri Tani Pemuka, 55\% crude protein, 5\% crude fat, $18 \%$ crude ash, $2 \%$ fiber and $11 \%$ moisture content). The feed was reformed into a paste or dough by mixing it with water (the ratio is $1 \mathrm{~g}$ feed: $0.25 \mathrm{ml}$ water). Feed making was carried out every sampling period by adjusting the fish biomass in the rearing container. Water management in the container was performed by siphonize and changing the water. The waste of feed eliminated by siphoned off before feeding and water change (as much as $20 \%$ of water volume in the container) ${ }^{10}$ is done twice a day (morning and evening).

Sampling of fish, blood and water. The data in this study were collected through weight, blood, water sampling on every 15 days during the maintenance period, while gills and liver sampling were collected before and after the maintenance period. Fish were removed from the maintenance container and placed in a sampling box, and then measured individually using the digital scale at $0.01 \mathrm{~g}$ accuracy. The blood sample was taken from the fish after being sedated with a stabilizer $(1 \mathrm{~mL} / 2 \mathrm{~L})$. Sample of blood was taken from the upper side between anus and anal fin end for hematology and blood chemistry analysis. Blood hematology sample was collected as much as $0.5 \mathrm{~mL}$ by a syringe filled with an anticoagulant (sodium-citrate) and distributed into the Eppendorf tube based on the treatment groups. Blood biochemistry sample was obtained as much as $1.5 \mathrm{~mL}$ without coagulant and distributed in the EDTA tube based on the treatment groups. Blood sampling was carried out for 10-15 min. The first blood sample was used for the hematological analysis and second blood sample was used for the blood biochemical analysis. Water sample was collected taking $250 \mathrm{~mL}$ water from the maintenance media and analyzed in the laboratory. The skin and gill samples were collected from the oversedated fish and cut in the head base to obtain the gill organs, while the back part was vertically cut to obtain the skin using scissors and tweezer. 


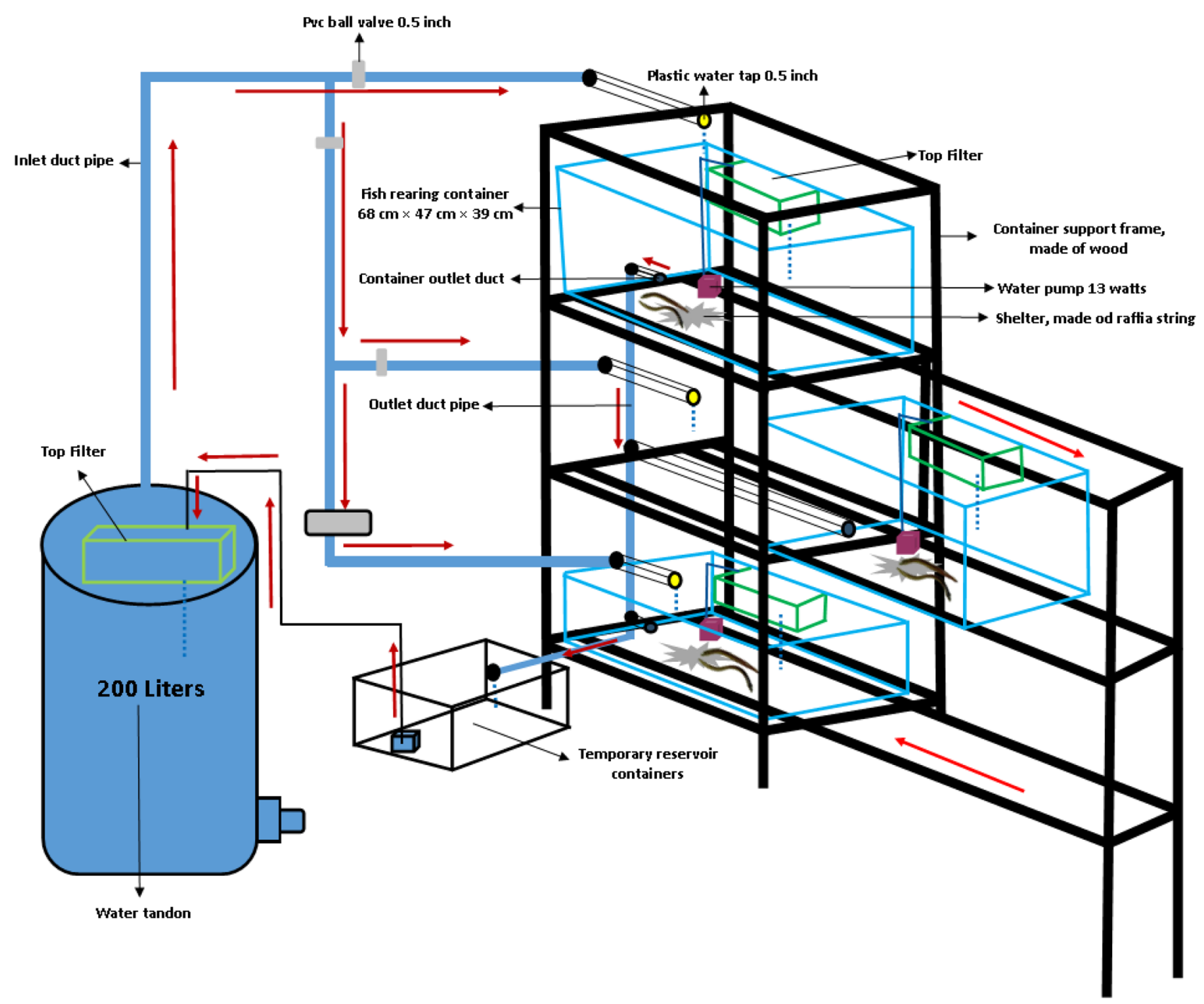

Figure 1. Experimental set up, vertical aquaculture systems (the container can be stretched horizontally to the front).

Measurement of production performance. The standard formulas used to determine the survival rate, SR $(\%)=\left(\mathrm{N}_{\mathrm{t}} / \mathrm{N}_{0}\right) \times 100$, whereas $\mathrm{N}_{\mathrm{t}}$ was the total final fish (fish) and $\mathrm{N}_{0}$ was the total initial fish (fish). Weight specific growth rate, $\mathrm{wSGR}(\%)=\left(\left(\ln \mathrm{w}_{\mathrm{t}}-\ln \mathrm{w}_{0}\right) / \mathrm{t}\right) \times 100$, whereas $\mathrm{t}$ was the maintenance period $=60$ days, $\mathrm{w}_{\mathrm{t}}=$ the average individual weight at 60 days $(\mathrm{g})$ and $\mathrm{w}_{0}=$ the average individual weight at 0 day $(\mathrm{g})$, absolute growth rate, AGR $(g /$ day $)=\left(w_{t}-w_{0}\right) / t$, biomass absolute growth rate, bAGR $(g /$ day $)=\left(B_{t}-B_{0}\right) / t$, whereas $\mathrm{B}_{\mathrm{t}}=$ biomass at 60 days $(\mathrm{g}), \mathrm{B}_{0}=$ biomass at 0 day $(\mathrm{g})$, feed conversion, $\mathrm{FCR}=$ consumed feed $(\mathrm{g}) /$ increased weight (g), weight diversity coefficient at 60 days, $\mathrm{wDC}(\%)=(100 \times \mathrm{SDW}) / \mathrm{W}$, whereas $\mathrm{W}$ was the average individual weight at 60 days $(\mathrm{g})$ and SDW was the weight standard deviation, oxygen consumption rate, OCR $\left(\mathrm{mgO}_{2}\right.$ $/ \mathrm{g} / \mathrm{h})=\mathrm{V} \times\left(\mathrm{DO}_{0}-\mathrm{DO}_{\mathrm{t}}\right) /(\mathrm{w} \times \mathrm{t})$, whereas $\mathrm{V}=$ water volume in the container $(\mathrm{L}), \mathrm{DO}_{0}=$ dissolved oxygen at 0 th period $(\mathrm{mg} / \mathrm{L}), \mathrm{DO}_{\mathrm{t}}=$ dissolved oxygen at the $t$ th period $(\mathrm{mg} / \mathrm{L}), \mathrm{w}=$ fish sample weight $(\mathrm{g})$. The OCR was measured by preparing the $5 \mathrm{~L}$ closed container with no air space remained and strong aeration for $24 \mathrm{~h}$. The aeration was removed, $\mathrm{DO}_{0}$ was measured and noted after the aeration was removed. Fish sample was measured and moved into the container, and then closed and measured the Dot each hour for $3 \mathrm{~h}^{29}$.

Blood biochemical analysis. The blood chemical parameters contained blood glucose (BG), total protein (TP), serum glutamic pyruvic transaminase (SGPT), serum glutamic oxaloacetic transaminase (SGOT), alkaline phosphatase (ALP), blood urea nitrogen (BUN) and creatinine. The analysis was performed using the blood chemical analyzer SPOTCHEM-EZ sp 4430 (ARKRAY Inc., Kyoto, Japan) equipped with the paper test indicator for each parameter. The blood biochemical analysis was performed in the Animal Hospital, Faculty of Animal Medicine, IPB University.

Hematological analysis. The total red blood cell (RBC) was calculated following ${ }^{30}$ by absorbing the blood sample with an absorbent pipette filled with red colored pulp stirrer until reaching scale 1 , and then added 
with the Hayem's solution until reaching scale 101, shaken for 3-5 min until homogenous. The first drop was removed and the blood was dropped into the hemacytometer enclosed with the cover glass and observed under the microscope. The calculation was performed on the small box of hemacytometer with the following formula: $\sum \mathrm{RBC}=\sum$ counted $\mathrm{RBC} \times 10^{6}$ cells $/ \mathrm{mm}^{3}$.

The total white blood cell (WBC) was calculated following ${ }^{30}$ by absorbing the blood sample with an absorbent pipette filled with white colored pulp stirrer until reaching $0.5 \mathrm{~mL}$ scale, and then added with the Turk's solution until reaching scale 11, shaken for $5 \mathrm{~min}$ until homogenous. The first drop was removed and the blood was dropped into the hemacytometer enclosed with the cover glass and observed under the microscope. The calculation was performed on the small box of hemacytometer with the following formula: $\sum \mathrm{WBC}=\sum$ counted $\mathrm{WBC} \times 10^{4}$ cells $/ \mathrm{mm}$.

The hemoglobin $(\mathrm{Hb})$ measurement was performed following the Sahli method with the Sahlinometer/Hb meter ${ }^{31}$. Blood was absorbed with the Sahli pipette until reaching $20 \mathrm{~mm}^{3}$ or $0.2 \mathrm{~mL}$ scales, then the pipette end was cleaned with tissue. Blood in the pipette was moved into the Hb-meter tube filled with $0.1 \mathrm{~N} \mathrm{HCl} \mathrm{until} \mathrm{reach-}$ ing scale 10 (red), then stirred and stood for 3-5 min. Aquadest was added into the blood sample and $\mathrm{HCl}$ until the color was similar to the $\mathrm{Hb}$ meter. The scale was read by observing the liquid surface and matched with the Sahli tube in the line scale of gr\% (yellow), which presented the hemoglobin content in gram per $100 \mathrm{ml}$ blood.

The hematocrit $(\mathrm{He})$ was calculated based $\mathrm{on}^{32}$. The blood sample was moved into the microhematocrit tube approximately reached 3/4 tube part, then the end of the tube was plugged with the $1 \mathrm{~mm}$ crystoseal and centrifuged at $5000 \mathrm{rpm}$ for $5 \mathrm{~min}$. The precipitated blood was measured its length (a) and total blood volume in the tube (b) using a ruler. The HE content was presented in \% solid blood cell volume and calculated following the formula: $\mathrm{HE}=(\mathrm{a} / \mathrm{b}) \times 100 \%$.

The leukocyte differentiation (LD) was calculated based on $^{30}$. Blood was dropped on the methanol-soaked sterile object glass and the end of the second object glass was placed on the blood dropped object glass until forming $30^{\circ}$ angle. The second object glass was moved to the back, while touching the blood drop until the blood spreaded and was stood until dry. The spreaded blood was fixated with the methanol absolute for 5 min, then removed and stood until dry. The blood sample staining was performed for $10 \mathrm{~min}$ in the Giemsa solution, then removed and rinsed with the flowing water, stood until dry. The blood smear was observed under the microscope at $1000 \times$ magnification. The leukocyte types were calculated their percentage from 100 leukocytes in several observational field. The hematological analysis was performed in the Fish Health Laboratory, Faculty of Fisheries and Marine Sciences, IPB University.

Histological analysis. The histological observation of gill and skin organs was performed following method $^{33}$ by fixating the organs with Bouin's solution and dehydrated into the serial alcohol from $70 \%$ until absolute, then infiltrated and blocker into the liquid paraffin. The histological samples were stained with the hematoxylin and eosin (HE), then observed under the microscope at $40 \times$ magnification. The analysis results in the form of figures were added with $50 \mu \mathrm{m}$ scale bar. The histological analysis was performed in the Fish Health Laboratory, Faculty of Fisheries and Marine Sciences, IPB University.

Water quality analysis. The water quality parameters containing temperature, $\mathrm{pH}$, and dissolved oxygen (DO) were directly measured every day using the mercury thermometer, Hanna HI98107 pH meter, and Lutron-5510 DO meter. TAN, ammonia, nitrite and alkalinity were analyzed using the spectrophotometer and Titimetrical method ${ }^{34,35}$. The water quality analysis was performed in Environmental laboratory, Faculty of Fisheries and Marine Sciences, IPB University.

Statistical analysis. The data obtained were tabulated with Microsoft Office Excel 2013 (Microsoft Corp., Washington, USA) and SPSS 22.0 (IBM Corp., New York, USA) for analysis of variance to determine the treatment effect in each parameter at $95 \%$ confidence level. Duncan test was performed when there were significant differences among treatment groups based on the parameters obtained.

\section{Results}

Production performance. Table 1 summarized production performance of eel elver after 60 days rearing period. Different water level treatments had no significant effect $(p>0.05)$ on the parameters of SR, WSGR, AGR, AGRoB, FCR, and OCR. Meanwhile, the results showed that the treatment had a significant effect $(p<0.05)$ on WCD. The highest value of WCD was indicated in treatment B of with $11.41 \%$. Relatively similar results were shown in treatment $\mathrm{A}$ and $\mathrm{C}$ with the values of $8.87 \%$ and $10.01 \%$, respectively. The lowest WCD was found in treatment D with $7.36 \%$.

Blood biochemistry. Different water level treatments had no significant effect $(p>0.05)$ on the parameters of BG, TP, SGPT, BUN, and creatinine. Meanwhile, the treatments had a significant effect $(p<0.05)$ on both SGOT and ALP (Table 2). The highest SGOT value was found in treatment A with $128.44 \mathrm{IU} / \mathrm{L}$. Treatment $\mathrm{C}$ and $\mathrm{D}$ shared somewhat similar results with $113.56 \mathrm{IU} / \mathrm{L}$ and $111.22 \mathrm{IU} / \mathrm{L}$, respectively. The lowest SGOT was found in treatment B with $100.11 \mathrm{IU} / \mathrm{L}$. The SGOT value decreased as compared to that before the treatments that showed $129.00 \mathrm{IU} / \mathrm{L}$. Meanwhile, the highest ALP value was found in treatment C with 288.89 IU/L. The lowest ALP value was shown in treatment A, which was $249.33 \mathrm{IU} / \mathrm{L}$. The values of treatment $\mathrm{B}$ and $\mathrm{D}$ were $267.44 \mathrm{IU} / \mathrm{L}$ and $225.72 \mathrm{IU} / \mathrm{L}$, respectively. The ALP value before the treatments was $265.00 \mathrm{IU} / \mathrm{L}$. The value indicated a decrease in treatment $\mathrm{A}$ and an increase in all other treatments. 


\begin{tabular}{|c|c|c|c|c|c|}
\hline \multirow[b]{2}{*}{ Item } & \multicolumn{5}{|c|}{ Water level } \\
\hline & $\mathbf{r}$ & $A(1.5 \mathrm{~cm})$ & $B(2.25 \mathrm{~cm})$ & $\mathrm{C}(3 \mathrm{~cm})$ & $\mathrm{D}(3.75 \mathrm{~cm})$ \\
\hline \multirow{3}{*}{ SR (\%) } & 1 & 100 & 100 & 100 & 100 \\
\hline & 2 & 100 & 100 & 100 & 100 \\
\hline & 3 & 100 & 100 & 100 & 100 \\
\hline Average \pm SD & & $100.00 \pm 0.00$ & $100.00 \pm 0.00$ & $100.00 \pm 0.00$ & $100.00 \pm 0.00$ \\
\hline \multirow{3}{*}{ WSGR (\%) } & 1 & 1.38 & 1.55 & 1.52 & 1.47 \\
\hline & 2 & 1.50 & 1.49 & 1.46 & 1.57 \\
\hline & 3 & 1.57 & 1.50 & 1.54 & 1.50 \\
\hline Average \pm SD & & $1.48 \pm 0.09^{\mathrm{a}}$ & $1.51 \pm 0.03^{\mathrm{a}}$ & $1.50 \pm 0.04^{\mathrm{a}}$ & $1.51 \pm 0.05^{\mathrm{a}}$ \\
\hline \multirow{3}{*}{ AGR (g/day) } & 1 & 0.29 & 0.35 & 0.34 & 0.32 \\
\hline & 2 & 0.33 & 0.33 & 0.32 & 0.35 \\
\hline & 3 & 0.34 & 0.32 & 0.34 & 0.34 \\
\hline Average \pm SD & & $0.32 \pm 0.03^{\mathrm{a}}$ & $0.33 \pm 0.02^{\mathrm{a}}$ & $0.33 \pm 0.01^{\mathrm{a}}$ & $0.33 \pm 0.02^{\mathrm{a}}$ \\
\hline \multirow{3}{*}{ AGRoB (g/day) } & 1 & 2.42 & 2.93 & 2.82 & 2.62 \\
\hline & 2 & 3.31 & 3.25 & 3.21 & 3.51 \\
\hline & 3 & 3.44 & 3.16 & 3.36 & 3.37 \\
\hline Average \pm SD & & $3.05 \pm 0.05^{\mathrm{a}}$ & $3.11 \pm 0.17^{\mathrm{a}}$ & $3.13 \pm 0.28^{\mathrm{a}}$ & $3.16 \pm 0.48^{\mathrm{a}}$ \\
\hline \multirow{3}{*}{ FCR } & 1 & 1.87 & 1.65 & 1.72 & 1.82 \\
\hline & 2 & 1.49 & 1.52 & 1.60 & 1.51 \\
\hline & 3 & 1.43 & 1.56 & 1.48 & 1.48 \\
\hline Average \pm SD & & $1.60 \pm 0.24^{\mathrm{a}}$ & $1.58 \pm 0.06^{\mathrm{a}}$ & $1.60 \pm 0.12^{\mathrm{a}}$ & $1.60 \pm 0.19^{\mathrm{a}}$ \\
\hline \multirow{3}{*}{ WCD (\%) } & 1 & 7.72 & 13.12 & 10.71 & 8.16 \\
\hline & 2 & 10.03 & 12.09 & 10.51 & 7.65 \\
\hline & 3 & 8.87 & 9.04 & 8.81 & 6.28 \\
\hline Average \pm SD & & $8.87 \pm 1.16^{\mathrm{ab}}$ & $11.41 \pm 2.12^{\mathrm{b}}$ & $10.01 \pm 1.04^{\mathrm{ab}}$ & $7.36 \pm 0.97^{\mathrm{a}}$ \\
\hline \multirow{3}{*}{$\mathrm{OCR}\left(\mathrm{mgO}_{2} / \mathrm{g} / \mathrm{h}\right)$} & 1 & 0.21 & 0.19 & 0.20 & 0.20 \\
\hline & 2 & 0.22 & 0.17 & 0.21 & 0.16 \\
\hline & 3 & 0.19 & 0.21 & 0.19 & 0.19 \\
\hline Average \pm SD & & $0.21 \pm 0.02^{\mathrm{a}}$ & $0.19 \pm 0.02^{\mathrm{a}}$ & $0.20 \pm 0.01^{\mathrm{a}}$ & $0.19 \pm 0.02^{\mathrm{a}}$ \\
\hline
\end{tabular}

Table 1. Production performance of $A$. bicolor bicolor reared for sixty days at several different water levels. Data are presented as mean \pm SEM. The values with same letters in the same line indicate non-significant differences $(p>0.05)$ in $5 \%$ significance level. One-way analysis of variance (ANOVA) followed by Duncan's multiple-range test was used to test significant differences among groups. $r$ repetition, $S R$ survival rate, WSGR weight-specific growth rate, $A G R$ absolute growth rate, $A G R o B$ absolute growth rate of biomass, FCR feed conversion ratio, WCD weight coefficient diversity, OCR oxygen consumption rate.

Hematology. The hematology is presented by several indicators, including RBC, WBC, Hb, He, and DL (monocytes, lymphocytes, and neutrophils) (Table 3). The treatments of different water levels had a significant effect $(p<0.05)$ on the He value with the highest value found in treatment $\mathrm{D}$ with $27.31 \%$. This value was the same as that of treatment $\mathrm{B}$, but different from those of treatment $\mathrm{A}$ and $\mathrm{C}$. The lowest He value was found in treatment $\mathrm{C}$ with $25.20 \%$. In general, the He value increased by $21.60 \%$ as compared to that before the treatment.

Gill and skin histology. The gill and skin histology at different water levels is shown in Fig. 2. The results showed that different water levels caused damages to the gills and skin. For instance, gill filament necrosis occurred in all treatments. The skin also experienced some changes in its histological structure, namely erosion, and irritation of its epidermis in all treatments.

Water quality. The water quality of eel elver rearing for 60 days showed that treatment had no significant effect on $\mathrm{pH}$, TAN, nitrite, ammonia, and alkalinity but had effect on temperature and DO (Table 4). In general, the water quality of rearing process was still in a proper condition for the cultivation of eel elver. The highest temperature was found in treatment $\mathrm{A}\left(28.48^{\circ} \mathrm{C}\right)$ and the lowest was in treatment $\mathrm{D}\left(27.01^{\circ} \mathrm{C}\right)$. The highest $\mathrm{DO}$ concentration was identified from treatment A $(5.28 \mathrm{mg} / \mathrm{L})$ and the lowest was from treatment B $(4.90 \mathrm{mg} / \mathrm{L})$. The concentration of $\mathrm{pH}$ ranged from 6.88 to 6.92 ; concentration of TAN ranged from 0.42 to $0.51 \mathrm{mg} / \mathrm{L}$; concentration of nitrite ranged from 0.84 to $1.58 \mathrm{mg} / \mathrm{L}$; concentration of ammonia ranged from 0.0024 to $0.0038 \mathrm{mg} / \mathrm{L}$; and concentration of alkalinity ranged from 13.42 to $16.42 \mathrm{mg} / \mathrm{L}$. 


\begin{tabular}{|c|c|c|c|c|c|c|}
\hline \multirow[b]{2}{*}{ Item } & \multicolumn{6}{|c|}{ Water level } \\
\hline & $\mathbf{r}$ & Before treatment & $A(1.5 \mathrm{~cm})$ & B $(2.25 \mathrm{~cm})$ & $\mathrm{C}(3 \mathrm{~cm})$ & $\mathrm{D}(3.75 \mathrm{~cm})$ \\
\hline \multirow{3}{*}{$\mathrm{BG}(\mathrm{mg} / \mathrm{dL})$} & 1 & \multirow{3}{*}{$61 \pm 22.52$} & 25.75 & 37.25 & 38.25 & 41.75 \\
\hline & 2 & & 32.75 & 23.25 & 21.75 & 37.75 \\
\hline & 3 & & 27.25 & 18.75 & 36 & 21 \\
\hline Average \pm SD & & & $28.58 \pm 3.69^{\mathrm{a}}$ & $26.42 \pm 9.65^{\mathrm{a}}$ & $32.00 \pm 8.95^{\mathrm{a}}$ & $33.50 \pm 11.01^{\mathrm{a}}$ \\
\hline \multirow{3}{*}{$\mathrm{TP}(\mathrm{g} / \mathrm{dL})$} & 1 & \multirow{3}{*}{$4.00 \pm 0.00$} & 3.17 & 3.50 & 3.43 & 3.50 \\
\hline & 2 & & 3.53 & 3.23 & 3.87 & 3.80 \\
\hline & 3 & & 3.40 & 3.43 & 3.60 & 3.60 \\
\hline Average \pm SD & & & $3.37 \pm 0.19^{\mathrm{a}}$ & $3.39 \pm 0.14^{\mathrm{a}}$ & $3.63 \pm 0.22^{\mathrm{a}}$ & $3.63 \pm 0.15^{\mathrm{a}}$ \\
\hline \multirow{3}{*}{ SGPT (IU/L) } & 1 & \multirow{3}{*}{$3.00 \pm 0.00$} & 1.00 & 1.00 & 1.00 & 1.00 \\
\hline & 2 & & 1.00 & 1.00 & 1.00 & 1.00 \\
\hline & 3 & & 1.00 & 1.00 & 1.00 & 1.00 \\
\hline Average \pm SD & & & $1.00 \pm 0.00^{\mathrm{a}}$ & $1.00 \pm 0.00^{\mathrm{a}}$ & $1.00 \pm 0.00^{\mathrm{a}}$ & $1.00 \pm 0.00^{\mathrm{a}}$ \\
\hline \multirow{3}{*}{ SGOT (IU/L) } & 1 & \multirow{3}{*}{$129.00 \pm 0.00$} & 115.33 & 109.00 & 118.33 & 122.00 \\
\hline & 2 & & 133.33 & 98.33 & 114.00 & 100.33 \\
\hline & 3 & & 136.67 & 93.00 & 108.33 & 111.33 \\
\hline Average \pm SD & & & $128.44 \pm 11.48^{\mathrm{a}}$ & $100.11 \pm 8.15^{\mathrm{b}}$ & $113.56 \pm 5.01^{\mathrm{ab}}$ & $111.22 \pm 10.83^{\mathrm{ab}}$ \\
\hline \multirow{3}{*}{ ALP (IU/L) } & 1 & \multirow{3}{*}{$265 \pm 0.00$} & 241.00 & 263.00 & 275.67 & 216.50 \\
\hline & 2 & & 238.00 & 268.00 & 313.50 & 231.67 \\
\hline & 3 & & 269.00 & 271.33 & 277.50 & 229.00 \\
\hline Average \pm SD & & & $249.33 \pm 17.10^{\mathrm{ab}}$ & $267.44 \pm 4.19^{\mathrm{bc}}$ & $288.89 \pm 21.33^{\mathrm{c}}$ & $225.72 \pm 8.10^{\mathrm{a}}$ \\
\hline \multirow{3}{*}{ BUN (mg/dL) } & 1 & \multirow{3}{*}{$5.00 \pm 0.00$} & 5.00 & 5.00 & 5.00 & 5.00 \\
\hline & 2 & & 5.00 & 5.00 & 5.00 & 5.00 \\
\hline & 3 & & 5.00 & 5.00 & 5.00 & 5.00 \\
\hline Average \pm SD & & & $5.00 \pm 0.00^{\mathrm{a}}$ & $5.00 \pm 0.00^{\mathrm{a}}$ & $5.00 \pm 0.00^{\mathrm{a}}$ & $5.00 \pm 0.00^{\mathrm{a}}$ \\
\hline \multirow{3}{*}{ Creatinine (mg/dL) } & 1 & \multirow{3}{*}{$0.90 \pm 0.00$} & 0.37 & 0.40 & 0.37 & 0.40 \\
\hline & 2 & & 0.43 & 0.40 & 0.40 & 0.40 \\
\hline & 3 & & 0.40 & 0.40 & 0.40 & 0.37 \\
\hline Average \pm SD & & & $0.40 \pm 0.03^{\mathrm{a}}$ & $0.40 \pm 0.00^{\mathrm{a}}$ & $0.39 \pm 0.02^{\mathrm{a}}$ & $0.39 \pm 0.02^{\mathrm{a}}$ \\
\hline
\end{tabular}

Table 2. Blood biochemistry parameters of A. bicolor bicolor reared for sixty days at several different water levels. Data are presented as mean \pm SEM. No statistical analyses were performed on fish before treatment. The values with same letters in the same line indicate non-significant differences $(p>0.05)$ in $5 \%$ significance level. One-way analysis of variance (ANOVA) followed by Duncan's multiple-range test was used to test significant differences among groups. $r$ repetition, $B G$ blood glucose, $T P$ total protein, $S G P T$ serum glutamic pyruvic transaminase, SGOT serum glutamic oxaloacetic transaminase, $A L P$ alkaline phosphatase, $B U N$ blood urea nitrogen.

\section{Discussion}

The production performance is a major parameter in the production of aquaculture biota that can indicate production success ${ }^{36}$. Based on Table 1, it can be seen that the production performance of the eel A. bicolor bicolor stadia elver in all treatments showed a significant increase. The SR in all treatments was $100 \%$ indicating that no death was found during the study. The values of WSGR, AGR, and AGRoB ranged from 1.48 to $1.51 \%$, 0.32 to $0.33 \mathrm{~g} /$ day, and 3.05 to $3.16 \mathrm{~g} /$ day, respectively. FCR and OCR ranged from 1.58 to 1.60 and 0.19 to $0.21 \mathrm{mgO}_{2} / \mathrm{g} / \mathrm{h}$, respectively. In general, this study shows better results than the previous studies about the use of water volume of culture media, individual growth rate, and biomass of the eel A. bicolor bicolor stadia elver reared for seventy days at a water volume of $0.4 \mathrm{~m}^{3}$ resulting in SR values of $97.98-98.54 \%$, WSGR $0.72 \%$, and FCR $1-1.72^{22}$. Meanwhile, the eel A. bicolor bicolor stadia elver with a size of $20 \mathrm{~g} / \mathrm{e}$ reared at a water level of $1.5 \mathrm{~cm}$ or as high as its body produced SR values of $66.67-100 \%$, WSGR $0.17-0.45 \%$, AGRoB $0.02-0.07 \mathrm{~g} / \mathrm{day}$, and FCR $6.57-23.08^{20}$. The results of this study are also better when compared to the cultivation of $A$. bicolor bicolor eels in the aquaponic system and phytoremediation using high water volume, the resulting SR value of $78-100 \%$, the growth was $0.3-1.19 \%$ and the KP was $1.57-3.91^{13,37}$. Besides, the growth in this study is higher than that of the eel $A$. bicolor bicolor stadia elver reared in a water volume of 48-120 L indicating the values between 0.2 and $1.47 \%$ for its WSGR ${ }^{10,11,13,38}$ and $0.8-3.48 \mathrm{~g} /$ day for its $\mathrm{AGR}^{12,38}$.

In the European eel A. Anguilla reared in different sizes, the results of WSGR and FC were $0.48-0.6 \%$ and $1.8-2.2$, respectively ${ }^{39}$. Meanwhile, WCD illustrates the level of weight diversity at the end of the rearing period. The higher the WCD value, the smaller the level of weight uniformity will be. The highest WCD in this study was found in treatment B with 11.41\%; this value was relatively similar to the values of treatment A and C, but different from the result of treatment $\mathrm{D}$ that showed only $7.36 \%$ of WCD. The WCD values in this study were still below $20 \%$, indicating that the weight uniformity rate of the eel A. bicolor bicolor stadia elver at the end of the 


\begin{tabular}{|c|c|c|c|c|c|c|}
\hline \multirow[b]{2}{*}{ Item } & \multicolumn{6}{|c|}{ Water level } \\
\hline & $\mathbf{r}$ & Before treatment & $\mathrm{A}(1.5 \mathrm{~cm})$ & B $(2.25 \mathrm{~cm})$ & $C(3 \mathrm{~cm})$ & $\mathrm{D}(3.75 \mathrm{~cm})$ \\
\hline \multirow{3}{*}{$\mathrm{RBCs}\left(\times 10^{6} \mathrm{sel} / \mathrm{mm}^{3}\right)$} & 1 & \multirow{3}{*}{$1.27 \pm 0.00$} & $1,490,000$ & $1,680,000$ & $1,370,000$ & $1,470,000$ \\
\hline & 2 & & $1,378,000$ & $1,608,000$ & $1,408,000$ & $1,520,000$ \\
\hline & 3 & & $1,570,000$ & $1,504,000$ & $1,592,000$ & $1,558,000$ \\
\hline Average \pm SD & & & $1.48 \pm 0.10^{\mathrm{a}}$ & $1.60 \pm 0.09^{\mathrm{a}}$ & $1.46 \pm 0.12^{\mathrm{a}}$ & $1.52 \pm 0.04^{\mathrm{a}}$ \\
\hline \multirow{4}{*}{$\mathrm{WBCs}\left(\times 10^{4} \mathrm{sel} / \mathrm{mm}^{3}\right)$} & 1 & \multirow{3}{*}{$9.27 \pm 0.00$} & 85,520 & 70,040 & 73,600 & 52,000 \\
\hline & 2 & & 60,540 & 82,200 & 71,680 & 76,360 \\
\hline & 3 & & 89,080 & 78,500 & 79,400 & 83,420 \\
\hline & & & $15,552.09$ & 6233.34 & 4019.22 & $16,484.69$ \\
\hline Average \pm SD & & & $7.84 \pm 1.56^{\mathrm{a}}$ & $7.69 \pm 0.62^{\mathrm{a}}$ & $7.49 \pm 0.40^{\mathrm{a}}$ & $7.06 \pm 1.65^{\mathrm{a}}$ \\
\hline \multirow{3}{*}{$\mathrm{Hb}$ (gram \%) } & 1 & \multirow{3}{*}{$7.20 \pm 0.00$} & 8.52 & 7.64 & 8.8 & 8 \\
\hline & 2 & & 8.4 & 8.9 & 9.34 & 8.72 \\
\hline & 3 & & 8.44 & 8.94 & 8.72 & 8.86 \\
\hline Average \pm SD & & & $8.45 \pm 0.06^{\mathrm{a}}$ & $8.49 \pm 0.74^{\mathrm{a}}$ & $8.95 \pm 0.34^{\mathrm{a}}$ & $8.53 \pm 0.46^{\mathrm{a}}$ \\
\hline \multirow{3}{*}{$\mathrm{He}(\%)$} & 1 & \multirow{3}{*}{$21.60 \pm 0.00$} & 26.26 & 27.4 & 24.24 & 26.6 \\
\hline & 2 & & 25.16 & 27.28 & 25.12 & 28.94 \\
\hline & 3 & & 26 & 28.34 & 26.24 & 26.4 \\
\hline Average \pm SD & & & $25.81 \pm 0.57^{\mathrm{a}}$ & $27.67 \pm 0.58^{\mathrm{b}}$ & $25.20 \pm 1.00^{\mathrm{a}}$ & $27.31 \pm 1.41^{\mathrm{b}}$ \\
\hline \multirow{3}{*}{ Monocytes (\%) } & 1 & \multirow{3}{*}{$25.20 \pm 0.00$} & 10.18 & 13.24 & 14.32 & 10.76 \\
\hline & 2 & & 10.8 & 15.2 & 13.9 & 20.28 \\
\hline & 3 & & 10.76 & 10.22 & 9.92 & 12.72 \\
\hline Average \pm SD & & & $10.58 \pm 0.35^{\mathrm{a}}$ & $12.89 \pm 2.51^{\mathrm{a}}$ & $12.71 \pm 2.43^{\mathrm{a}}$ & $14.59 \pm 5.03^{\mathrm{a}}$ \\
\hline \multirow{3}{*}{ Lymphocytes (\%) } & 1 & \multirow{3}{*}{$61.80 \pm 0.00$} & 74.56 & 72.84 & 72.88 & 76.66 \\
\hline & 2 & & 69.48 & 70.68 & 71.6 & 66.2 \\
\hline & 3 & & 75.44 & 74.16 & \begin{tabular}{|l|}
76.38 \\
\end{tabular} & 71.24 \\
\hline Average \pm SD & & & $73.16 \pm 3.22^{\mathrm{a}}$ & $72.56 \pm 1.76^{\mathrm{a}}$ & $73.62 \pm 2.47^{\mathrm{a}}$ & $71.37 \pm 5.23^{\mathrm{a}}$ \\
\hline \multirow{3}{*}{ Neutrophils(\%) } & 1 & \multirow{3}{*}{$13.00 \pm 0.00$} & 15.26 & 14.5 & 12.8 & 12.58 \\
\hline & 2 & & 19.76 & 14.1 & 14.48 & 13.52 \\
\hline & 3 & & 13.78 & 15.62 & 13.7 & 16.04 \\
\hline Average $\pm S D$ & & & $16.27 \pm 3.11^{\mathrm{a}}$ & $14.74 \pm 0.79^{\mathrm{a}}$ & $13.66 \pm 0.84^{\mathrm{a}}$ & $14.05 \pm 1.79^{\mathrm{a}}$ \\
\hline
\end{tabular}

Table 3. Hematology parameters of A. bicolor bicolor reared for sixty days at several different water. Data are presented as mean \pm SEM. No statistical analyses were performed on fish before treatment. The values with same letters in the same line indicate non-significant differences $(p>0.05)$ in $5 \%$ significance level. One-way analysis of variance (ANOVA) followed by Duncan's multiple-range test was used to test significant differences among groups. $r$ repetition, $R B C s$ red blood cells, $W B C s$ white blood cells, Hb hemoglobin, He hematocrit.

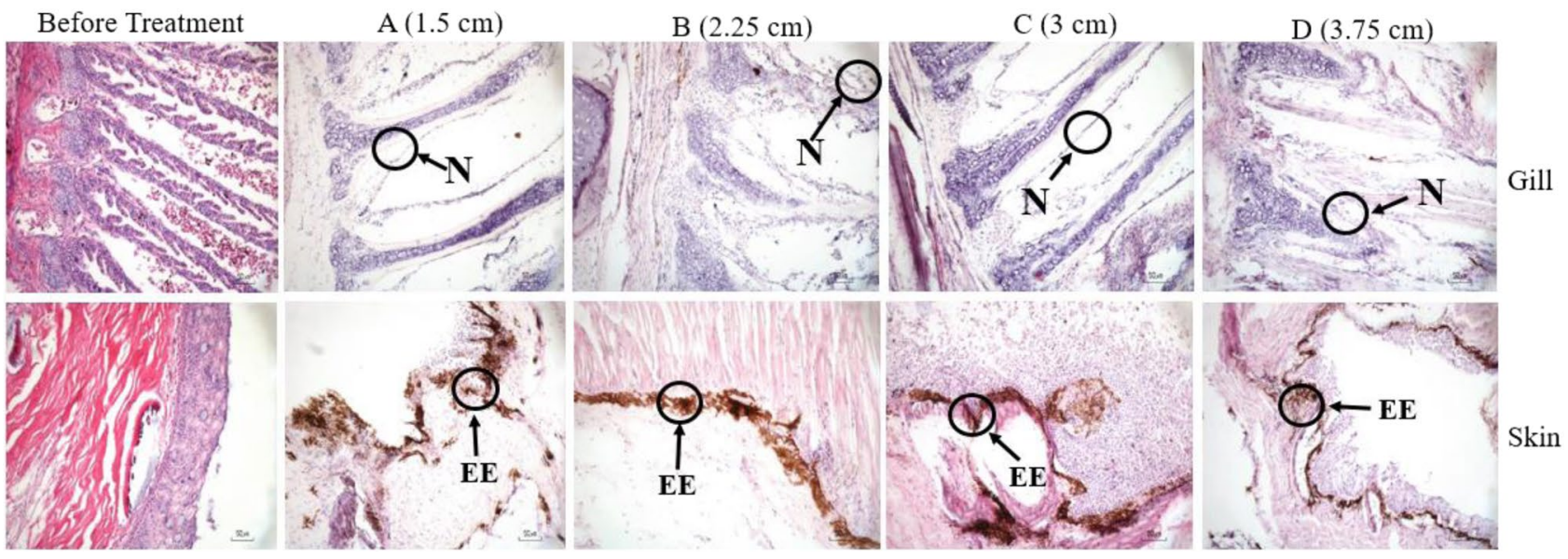

Figure 2. Histology of gill and skin A. bicolor bicolor reared for sixty days at several different water levels. $\mathrm{N}=$ necrosis, $\mathrm{EE}=$ erosion of epidermis, Hematoxylin-Eosin $40 \times(\mathrm{f}) \mathrm{bar}=50 \mu \mathrm{m}$. 


\begin{tabular}{|c|c|c|c|c|c|c|}
\hline \multirow[b]{2}{*}{ Water quality } & \multicolumn{6}{|c|}{ Treatment (water level) } \\
\hline & $\mathbf{r}$ & $A(1.5 \mathrm{~cm})$ & B $(2.25 \mathrm{~cm})$ & $\mathrm{C}(3 \mathrm{~cm})$ & $\mathrm{D}(3.75 \mathrm{~cm})$ & $\begin{array}{l}\text { Optimum value } \\
\text { (references) }\end{array}$ \\
\hline \multirow{3}{*}{ Temperature $\left({ }^{\circ} \mathrm{C}\right)$} & 1 & 28.82 & 28.82 & 27.81 & 27.02 & \multirow{3}{*}{$23-32^{95}$} \\
\hline & 2 & 27.81 & 27.81 & 28.78 & 27.02 & \\
\hline & 3 & 28.82 & 27.81 & 26.98 & 26.98 & \\
\hline Average \pm SD & $28.48 \pm 0.58^{\mathrm{b}}$ & $28.15 \pm 0.58^{\mathrm{ab}}$ & $27.86 \pm 0.90^{\mathrm{ab}}$ & $27.01 \pm 0.03^{\mathrm{a}}$ & & \\
\hline \multirow{3}{*}{$\mathrm{pH}$} & 1 & 6.91 & 6.88 & 6.89 & 6.91 & \multirow{3}{*}{$6-8^{96}$} \\
\hline & 2 & 6.91 & 6.88 & 6.92 & 6.89 & \\
\hline & 3 & 6.85 & 6.90 & 6.94 & 6.84 & \\
\hline Average \pm SD & $6.89 \pm 0.03^{\mathrm{a}}$ & $6.89 \pm 0.01^{\mathrm{a}}$ & $6.92 \pm 0.02^{\mathrm{a}}$ & $6.88 \pm 0.04^{\mathrm{a}}$ & & \\
\hline \multirow{3}{*}{$\mathrm{DO}(\mathrm{mg} / \mathrm{L})$} & 1 & 5.35 & 5.04 & 4.91 & 5.21 & \multirow{3}{*}{$>3.0^{98}$} \\
\hline & 2 & 5.39 & 5.00 & 5.15 & 5.32 & \\
\hline & 3 & 5.09 & 4.67 & 4.94 & 4.92 & \\
\hline Average \pm SD & $5.28 \pm 0.16^{\mathrm{b}}$ & $4.90 \pm 0.20^{\mathrm{ab}}$ & $5.00 \pm 0.13^{\mathrm{ab}}$ & $5.15 \pm 0.21^{\mathrm{a}}$ & & \\
\hline \multirow{3}{*}{ TAN (mg/L) } & 1 & 0.72 & 0.40 & 0.51 & 0.44 & \multirow{3}{*}{$<0.25^{96}$} \\
\hline & 2 & 0.38 & 0.41 & 0.43 & 0.43 & \\
\hline & 3 & 0.43 & 0.52 & 0.34 & 0.39 & \\
\hline Average \pm SD & $0.51 \pm 0.19^{\mathrm{a}}$ & $0.44 \pm 0.07^{\mathrm{a}}$ & $0.42 \pm 0.09^{\mathrm{a}}$ & $0.42 \pm 0.03^{\mathrm{a}}$ & & \\
\hline \multirow{3}{*}{ Nitrite $(\mathrm{mg} / \mathrm{L})$} & 1 & 0.94 & 0.99 & 1.90 & 1.96 & \multirow{3}{*}{$<0.5^{99}$} \\
\hline & 2 & 0.46 & 1.03 & 1.30 & 1.05 & \\
\hline & 3 & 1.13 & 1.87 & 1.31 & 1.74 & \\
\hline Average \pm SD & $0.84 \pm 0.34^{\mathrm{a}}$ & $1.30 \pm 0.50^{\mathrm{a}}$ & $1.50 \pm 0.34^{\mathrm{a}}$ & $1.58 \pm 0.47^{\mathrm{a}}$ & & \\
\hline \multirow{3}{*}{ Ammonia (mg/L) } & 1 & 0.0044 & 0.0035 & 0.0045 & 0.0024 & \multirow{3}{*}{$<0.1^{94}$} \\
\hline & 2 & 0.0022 & 0.0038 & 0.0026 & 0.0028 & \\
\hline & 3 & 0.0035 & 0.0033 & 0.0042 & 0.0021 & \\
\hline Average \pm SD & $0.0034 \pm 0.0011^{\mathrm{a}}$ & $0.0035 \pm 0.0003^{\mathrm{a}}$ & $0.0038 \pm 0.0010^{\mathrm{a}}$ & $0.0024 \pm 0.0003^{a}$ & & \\
\hline \multirow{3}{*}{ Alkalinity (mg/L) } & 1 & 11.50 & 20.00 & 15.50 & 15.75 & \multirow{3}{*}{$30-500^{102,103}$} \\
\hline & 2 & 13.00 & 14.25 & 15.50 & 15.00 & \\
\hline & 3 & 15.75 & 14.75 & 18.25 & 18.25 & \\
\hline Average \pm SD & $13.42 \pm 2.16^{\mathrm{a}}$ & $16.33 \pm 3.19^{\mathrm{a}}$ & $16.42 \pm 1.59^{\mathrm{a}}$ & $16.33 \pm 1.70^{\mathrm{a}}$ & & \\
\hline
\end{tabular}

Table 4. Water quality parameters of A. bicolor bicolor reared for sixty days at several different water levels. Data are presented as mean \pm SEM. The values with same letters in the same line indicate non-significant differences $(p>0.05)$ in $5 \%$ significance level. One-way analysis of variance (ANOVA) followed by Duncan's multiple-range test was used to test significant differences among groups. $r$ repetition, ${ }^{95}$ Ritonga $(2014),{ }^{96}$ Tseng and Wu (2004), ${ }^{98}$ Herianti (2005), ${ }^{99}$ Knosche (1994), ${ }^{94} \mathrm{KKP}(2011),{ }^{102}$ Wahyudi et al. (2015); ${ }^{103}$ Chaudhary and Pillai (2008).

study was high ${ }^{40}$. This study has better results of the WCD values than the previous studies where the eels were reared in a water volume of $48-120 \mathrm{~L}$ with the WCD value ranging from 12 to $39 \%^{10-12}$. OCR functions as an indicator to determine the metabolic rate of fish ${ }^{41}$. The lower the TKO rate, the less energy used for metabolism that more energy available for growth. The results showed that OCR ranged from 0.19 to $0.20 \mathrm{mgO}_{2} / \mathrm{g} / \mathrm{h}$. The values are lower than those of the previous studies with $0.26-0.4 \mathrm{mgO}_{2} / \mathrm{g} / \mathrm{h}$ of $\mathrm{OCR}^{42,43}$.

In general, the water level treatment in this study did not show any significant effect $(p<0.05)$ on the production performance parameters. It implies that the water level in the treatment is still within normal limits to support SR and the growth of the fish. In terms of water use efficiency, the lowest water level is the most efficient treatment in using water for the cultivation of the eel A. bicolor bicolor.

Blood biochemistry is a secondary response of fish to environmental changes and pathogenic infections that cause fish to be in a stressful state due to the release of several stress hormones ${ }^{44}$. This secondary response is also characterized by changes in blood and tissue biochemistry, such as the increase of blood glucose $\mathrm{e}^{45,46}$. It eventually results in a large amount of energy used by fish to adapt to the conditions ${ }^{47}$. Apart from blood glucose, biochemistry changes in the blood are also used in evaluating the health or stress condition of fish ${ }^{48-50}$. According to Table 2, different water levels gave no significant effect $(p>0.05)$ on the parameters of BG, TP, SGPT, BUN, and creatinine. In general, the blood biochemistry responses are still in normal conditions (no stress).

The normal values of BG, BUN, and creatinine in the fish range from 29 to $43 \mathrm{mg} / \mathrm{dL}^{51}, 1.8-7.1 \mathrm{mg} / \mathrm{dL}$, and $0.8-1.5^{52}$. Several previous studies also showed various BG between 41.17 and $246 \mathrm{mg} / \mathrm{dL}^{42,53-55}$. The TP value in this study ranged from 3.63 to $3.39 \mathrm{~g} / \mathrm{dL}$. This value was lower than that before the treatments. The TP value in this study does not show a big difference from the values of other studies that ranged from 3.90 to $5.11 \mathrm{~g} / \mathrm{dL}^{56-58}$. The SGPT value in this study was $1 \mathrm{IU} / \mathrm{L}$; it is lower than that before the treatments. Besides, this value is much lower than the values of other species, such as $A$. marmorata with $4.53-8.27 \mathrm{IU} / \mathrm{L}^{59}$, Esox 
Lucius with 4.9-11.2 IU/L, Salmo solar with 6 IU/L, Salmo trutta with 1.19-41.99 IU/L, and Timalus timalus with $0.59-71.98 \mathrm{IU} / \mathrm{L}^{60}$. The SGPT values are influenced by fish species ${ }^{61}$. BUN and creatinine are indicators for kidney organ damage. The increase of BUN indicates the declining ability of the kidneys to excrete urea in the blood. It is also in line with the creatinine; the increase of the creatinine signifies damage to the kidney organs $\mathrm{s}^{52}$. In this study, the BUN and creatinine values were $5 \mathrm{mg} / \mathrm{dL}$ and $0.39-0.40 \mathrm{mg} / \mathrm{dL}$, respectively. Other studies show somewhat similar results, for example Clarias gariepinus with $0.00-6.30 \mathrm{mg} / \mathrm{dL}$ and $0.00-2.90 \mathrm{mg} / \mathrm{dL}^{52}$, Gymnothorax vicinus with $<11$ and $26-31 \mathrm{mg} / \mathrm{dL}^{62}$, Notopterus notopterus with the values of 2.20 and $0.69 \mathrm{mg} / \mathrm{dL}^{63}$.

The water level treatment had a significant effect $(p<0.05)$ on SGOT and ALP. The highest SGOT value was found in treatment A with $128.44 \mathrm{IU} / \mathrm{L}$. Treatment C and D showed relatively similar findings; and the lowest SGOT was found in treatment B with the value of $100.11 \mathrm{IU} / \mathrm{L}$. The SGOT value after the treatments was lower than that before the treatments. In A. marmoratta, with different density, the SGOT values ranged from 114 to $183 \mathrm{IU} / \mathrm{L}^{59}$. Meanwhile, the values of other species include Esox lucius with 252-583 IU/L, Thymallus thymallus with 59.98-119.97 IU/L, Salmo trutta with 71.98-719.85 IU/L, and Salmo salar with 278 IU/L ${ }^{60}$, Gymnothorax vicinus with $108 \mathrm{IU} / \mathrm{L}^{62}$, Oreochromis niloticus with 139-204 IU/L $\mathrm{L}^{64}$. The highest ALP value was found in treatment $\mathrm{C}$ with a value of $288.89 \mathrm{IU} / \mathrm{L}$. The lowest ALP value was found in treatment A, which was $249.33 \mathrm{IU} / \mathrm{L}$. The values of treatment $B$ and D were 267.44 IU/L and 225.72 IU/L, respectively. The ALP value before the treatments was $265.00 \mathrm{IU} / \mathrm{L}$. This value showed a decrease in treatment $\mathrm{A}$ and an increase in other treatments as compared to that before the treatments. In another study investigating the species of A. anguilla, it was found that the rise of ALP value greater than $50 \%$ was due to the exposure of propenyl; the controlled ALP value was $35.46 \mathrm{IU} / \mathrm{L}^{65}$. The ALP value also varies in the A. bicolor eel found in different seasons with $98.6-154.7 \mathrm{IU} / \mathrm{L}^{66}$.

The hematology is a significant indicator in aquaculture as it can provide an evaluation of the health status of fish due to changes in nutrition, water quality, and disease; besides, it can be done in a non-lethal way ${ }^{54,67}$. The hematological in this study showed relatively similar responses in all treatments $(p>0.05)$. These responses were still in normal conditions (no stress). The normal RBCs values are in the range of $1.01-2.43 \times 106$ cells/ $\mathrm{mm}^{33,10,11,20,68}$. Other studies also showed an increase of the RBCs values with $1.59-1.79 \times 106 \mathrm{cells} / \mathrm{mm}^{3}$ and $1.59-1.79 \times 106$ cells $/ \mathrm{mm}^{33,20}$. WBCs have been used in the clinical evaluation of stress and fish disease ${ }^{71}$. In this study, the number of WBCs showed a decline in the amount of $9.27-7.06 \times 104$ cells $/ \mathrm{mm}^{3}$. However, this decline is still within the normal range. The normal SDP of fish is in the range between 3.60 and $7.58 \times 104$ cells $/ \mathrm{mm}^{372}$. The decrease in WBCs was also reported at the level of $8.1-5.4 \times 104$ cells $/ \mathrm{mm}^{370}$. The low number of WBC implies that the fish are healthy and have a good immune response $\mathrm{e}^{73,74}$.

$\mathrm{Hb}$ functions as an indicator that shows the blood ability to carry oxygen ${ }^{73}$. The values of $\mathrm{Hb}$ in this study ranged from 8.45 to $8.93 \mathrm{~g} \%$; this shows a normal range for the eels. The normal $\mathrm{Hb}$ values in a fish range from 4 to $11 \mathrm{~g} \%{ }^{20,42,68,75}$. Meanwhile, He is the ratio between RBCs volume and total blood volume ${ }^{76}$. In this study, the water level treatments had a significant effect $(p<0.05)$ on the He value. The highest value was found in treatment $\mathrm{D}$ with $27.31 \%$. This result was similar to that of treatment $\mathrm{B}$, but different from those of treatment $\mathrm{A}$ and $\mathrm{C}$. The lowest $\mathrm{He}$ value was in treatment $\mathrm{C}$ that was $25.20 \%$. In general, the He value increased by $21.60 \%$ as compared to that before the treatments. In general, the He value in this study is still in the normal range. The normal $\mathrm{He}$ value in the eel's blood of eel is between 26 and $36 \%{ }^{72,77}$.

Leukocyte differentiation which includes monocytes, lymphocytes, and neutrophils is a derivative of WBCs ${ }^{70}$. The comparison among monocytes, neutrophils, and lymphocytes has been an excellent indicator for measuring the stress level of fish ${ }^{78}$. In this study, the monocytes of the initial conditions before the treatments were $25.20 \%$. After the treatments, the monocytes increased by $10.58-14.59 \%$. The monocytes showed a very low percentage; it is in line with ${ }^{79}$. The lymphocytes in the initial condition before the treatments was $61.80 \%$. Then, it showed various results after the treatments ranging from 71.37 to $73.62 \%$. The decrease of monocytes is due to the increase of lymphocytes produced by antibodies ${ }^{80}$. Similar to the lymphocytes, the neutrophils also showed the same response, in which it was low before the treatments began and increased as the treatments proceeded. Another study found that eels weighing $120 \mathrm{~g}$ had $100 \mathrm{WBCs}, 34-70 \%$ lymphocytes, and 8-29\% neutrophil granulocytes ${ }^{81}$.

The results of the histological analysis showed that the eels reared at different water levels indicated several changes of their histological structure, which is gill and skin damage (Fig. 1). Filament necrosis occurred in the gill organs for all treatments. The skin also experienced some erosion on its epidermis for all treatments. The changes in the histology structure that occurred were due to the fact that eels were in a very low water level, thus providing a moment for gills and skin to be in direct contact with air. This condition allows the uptake of air gases continuously and causes irritation to the gills and skin organs. Changes in the histology structure did not significantly affect the production performance and health status of eels in all treatments. Production performance escalated with increasing water level. SR values that reach $100 \%$ and significant growth are important indicators that the fish are in good health status. Necrosis and hyperplasia also occurred in A. japonica due to the exposure to mercury and infection of Herpesvirus anguillae ${ }^{82,83}$. Changes in the histology structure also occur in several vital organs due to diseases and contaminants ${ }^{20,84-87}$. Erosion on its epidermis occurred because the skin was in direct contact with air continuously and caused the outer part of the skin to fade. Changes in the histology structure of the skin did not have a negative effect on other parameters (production performance and physiological responses), eels showed good production performance with undisturbed health status due to treatment. Eels are strong species and able to withstand extreme conditions, this is supported by a strong and thick skin structure ${ }^{88}$. It is capable to protect the body surface from chemical damage and infection of microorganisms ${ }^{1,84,89-91}$. The results of other studies also show the same symptoms, namely the thinning or erosion of epidermal cells due to pathogenic infections ${ }^{92}$.

In general, the water quality parameters were still in the optimum range for all treatments. The highest temperature concentration was found in treatment $\left(28.48^{\circ} \mathrm{C}\right)$ and the lowest was in treatment $\mathrm{D}\left(27.01{ }^{\circ} \mathrm{C}\right)$. It was still in the normal conditions for the eel rearing. The optimal temperature range for eel rearing itself ranges from 22 to $33^{\circ} \mathrm{C}^{42,93-95}$. The concentration of $\mathrm{pH}$ during the study ranged from 6.88 to 6.92 it was still under the normal 
conditions for eel rearing. The optimal $\mathrm{pH}$ range in the eel rearing ranges between 6 and $8^{94-96}$. The highest DO concentration was identified from treatment A $(5.28 \mathrm{mg} / \mathrm{L})$ and the lowest was from treatment B $(4.90 \mathrm{mg} / \mathrm{L})$, it was below the normal conditions for the rearing as the optimal rate for the eel rearing is $>3.0 \mathrm{mg} / \mathrm{L}^{94,97,98}$.

The concentration of TAN in this study ranged between 0.42 and $0.51 \mathrm{mg} / \mathrm{L}$, which was below the normal conditions for eel rearing, the optimal value of TAN for eel rearing is $<0.25 \mathrm{mg} / \mathrm{L}^{96}$. The concentration of nitrite in this study ranged from 0.84 to $1.58 \mathrm{mg} / \mathrm{L}$, which was still under normal conditions. The ideal concentration of nitrite in the eel rearing is $<0.5 \mathrm{mg} / \mathrm{L}^{99}$, and $<0.1 \mathrm{mg} / \mathrm{L}^{96}$. Nitrite is less toxic than ammonia with a tolerance level of $0.4-0.8 \mathrm{mg} / \mathrm{L}^{100}$. The concentration of ammonia ranged from 0.0024 to $0.0038 \mathrm{mg} / \mathrm{L}$, which is below the best conditions for eel rearing. The best range of ammonia in eel rearing is $<0.1 \mathrm{mg} / \mathrm{L}^{94,96,101}$. Alkalinity ranged between 13.42 and $16.42 \mathrm{mg} / \mathrm{L}$. These conditions are ideal for eel rearing as the optimal alkalinity for the eel rearing is $30-500 \mathrm{mg} / \mathrm{L}^{102,103}$. The normal conditions of the water quality in this study were highly influenced by the use of a recirculation system. The recirculation system is an intensification of fish production by reusing the rearing water and processing the water to depurate $\mathrm{it}^{104-106}$. Water management is carried out by using filters to reduce fish culture waste and feed remains ${ }^{107,108}$.

Elver eels A. bicolor bicolor could be reared in a container arranged vertically with a recirculation system and in most cases give the same responses to different water levels. The water level of $1.5 \mathrm{~cm}$ provides advantage in several ways namely the least in water use and gives blood biochemistry values that are the closest to normal condition, also the best concentration of temperature and DO.

Ethics declaration. We ensured that the experiments followed the ethical guidelines of IPB University and confirmed that all experimental protocols were approved by IPB University.

\section{Data availability}

The datasets generated during and/or analysed during the current study are available from the corresponding author on reasonable request.

Received: 26 December 2020; Accepted: 11 May 2021

Published online: 31 May 2021

\section{References}

1. Arai, T., Kadir, S. R. A. \& Chino, N. Year-round spawning by a tropical catadromous eel Anguilla bicolor bicolor. Aquat. Ecol. 163(2), 37 (2016).

2. Tesch, F. W. The Eel (Blackwell, 2003).

3. Tomiyama, T. \& Hibiya, T. Fisheris in Japan (eel). Japan: Japan Marine Product Photo Materials Association. 225 pp. (1977).

4. Affandi, R. Strategi pemanfaatan sumberdaya ikan sidat (Anguilla spp.) di Indonesia. J. lktiologi Indones. 5(2), 77-81 (2005).

5. Aoyama, J. Live history and evolution of migration in catadromous eels (Genus Anguilla). Aquaculture BioSci Monogr 2(1), 1-42 (2009).

6. Hyde, D. A., Moon, T. W. \& Perry, S. F. Physiological consequences of prolonged aerial exposure in the American eel, Anguilla rostrata: Blood respiratory and acid-base status. J. Comp. Physiol. B 157(5), 635-642 (1987).

7. McArthur, C. P. Haematology of the New Zealand freshwater eels Anguilla australis schmidtii and A. dieffenbachii. N.Z. J. Zool. 4(1), 5-20 (1977).

8. Cao, Q. et al. Physiological mechanism of osmoregulatory adaptation in anguillid eels. Fish. Physiol. Biochem. 44(2), 423-433 (2018).

9. Van Ginneken, V., Hekman, M. \& Verheij, E. The lipid composition and biochemistry of the migrating European eel (Anguilla anguilla L.): a LCMS-study following a lipidomics based systems biology approach. Adv. Biochem. Biotehcnol. ABIO-165 (2018).

10. Harianto, E., Budiardi, T. \& Sudrajat, A. O. Growth performance of 7-g Anguilla bicolor bicolor at different density. J. Akuakultur Indones. 13, 120-131 (2014).

11. Diansyah, S., Budiardi, T. \& Sudrajat, A. O. Growth performance of 3-g Anguilla bicolor bicolor at different density. J. Akuakultur Indones. 13, 46-53 (2014).

12. Scabra, A. R., Budiardi, T. \& Djokosetiyanto, D. Production performance of Anguilla bicolor bicolor with the addition of CaCO 3 into culture media. J. Akuakultur Indones. 1, 1-7 (2016).

13. Handajani, H., Widanarni, Setiawati, M., Budiardi, T. \& Sujono. Evaluation of digestibility and ammonia excretion of fish meal and fish silage fed to juvenile Indonesian shortfin eel (Anguilla bicolor). AACL Bioflux 11, 495-504 (2018).

14. FAO [Food and Agriculture Organization of the United Nations]. Anguilla japonica. In: J. Xie, V. Crespi, M. New. (Eds.), Cultured aquatic species fact sheets. CD-ROM (multilingual), (2009).

15. Handoyo, B., Garnawansah, G., Murdjani, S. A. \& Supendi, P. Paket teknologi pendederan dan pembesaran ikan sidat di BLUPPB Karawang. Aquac. Bus. Food Sec., 1(1), 1-13 (2016).

16. Mordenti, O., Di Biase, A., Casalini, A., Emmanuele, P., Melotti, P. \& Roncarati, A. Growth performances and natural diet of European eel (Anguilla anguilla L.) reared in muddy and sandy ponds. Aquat. Liv. Resour. 29(1), 105, (2016).

17. Methling, C., Tudorache, C., Skov, P. V. \& Steffensen, J. F. Pop up satellite tags impair swimming performance and energetics of the European eel (Anguilla anguilla). PLoS ONE 6(6), e20797 (2011).

18. Affandi, R. Pengembangan sumber daya ikan sidat (Anguilla spp.) di Indonesia. In M. S. Baskoro (Eds). Teknologi Pengembangan Perikanan dan Kelautan untuk Memperkuat Ketahanan Pangan serta Memacu Perekonomian Nasional Secara Berkelanjutan (pp 151-200). IPB Press, (2015).

19. Usui, A. Eel culture. 186 pp. (Fishing News, West Byfleet \& London) (1974).

20. Harianto, E., Supriyono, E., Budiardi, T., Affandi, R. \& Hadiroseyani, Y. Production performance and physiology response of Anguilla bicolor bicolor rearing with a wet, damp and dry system. J. Iktiologi Indones. 20, 117-132 (2020).

21. Taufiq-Spj, N., Sunaryo, S., Wirasatria, A. \& Sugianto, D.N. The use of water exchange for feeding rate and growth promotion of shortfin eel Anguilla bicolor bicolor in recirculating water system. (IOP Publishing Ltd. Web., 2017).

22. Taufiq-Spj, N. et al. The use of different water volume to measure the growth and survival rates of Anguilla bicolor caught from Nusawungu riverines, Cilacap, Indonesia. AACL Bioflux 13, 1473-1482 (2020).

23. Goddek, S., Joyce, A., Kotzen, B. \& Burnell, G. M. Aquaponics food production systems-combined aquaculture and hydroponic production technologies for the future (Springer, 2019).

24. Touliatos, D., Dodd, I. C. \& McAinsh, M. Vertical farming increases lettuce yield per unit area compared to conventional horizontal hydroponics. Food Energy Secur. 5, 184-191 (2016). 
25. Muller, A., Ferré, M., Engel, S., Gattinger, A., Holzkämper, A., Huber, R., Müller, M. \& Six J. Can soil-less crop production be a sustainable option for soil conservation and future agriculture. Land Use Policy. 69, 102-105 https://doi.org/10.1016/j.landu sepol.2017.09.014 (2017).

26. Delaide, B. et al. Plant and fish production performance, nutrient mass balances, energy and water use of the PAFF Box, a smallscale aquaponic system. Aquacult. Eng. 78, 130-139 (2017).

27. Jeffs, A. G. \& James, P. Sea-cage culture of the spiny lobster Jasus edwardsii in New Zealand. J. Mar. Freshw. Res. 52, 1419-1424 (2001).

28. Shelley, C. \& Lovatelli, A. Mud crab aquaculture-A practical manual. FAO Fisheries and Aquaculture Technical Paper. No. 567. Rome. 78 hlm (2011).

29. NRC [National Research Council]. Nutrient requirements of warmwater fishes. (National Academy Science, Washington) (1977).

30. Blaxhall, P. C. \& Daishley, K. W. Routine haematological methods for use with fish blood. J. Fish Biol. 5, 577-581 (1973).

31. Wedemeyer, G.A., Yasutake, W.T. Clinical methods for the assessment of the effect environmental stress on fish health. Department of Interior Fish and Wildlife Service Technical, New York (1977).

32. Anderson, D. P. \& Siwicki, A. K. Basic Hematology and Serology for Fish Health Programs. Paper presented in second symposium on diseases in Asian Aquaculture "Aquatic Animal Health and the Environment". Phuket, Thailand. 25-29th October 1993, pp. 185-202 (1993).

33. Angka, S. L., Mokoginta, I. \& Hamid, H. Anatomi dan Histologi Banding Beberapa Ikan Air Tawar yang Dibudidayakan di Indonesia. Departemen Pendidikan dan Kebudayaan. Direktorat Jenderal Pendidikan Tinggi. (Institut Pertanian Bogor, Bogor) (1990).

34. [APHA] American Public Health Association. Standard Methods for the Examination of the Water and Wastewater. 2th ed. Washington DC: American Public Health Association. (2006).

35. Tseng, K. F. \& Wu, K. L. The ammonia removal cycle for a submerged biofilter used in a recirculating eel culture system. Aquacult. Eng. 31(1-2), 17-30 (2004).

36. Hartnoll, R. G. Growth. In: Able, L. G. (Ed) The biology of Crustacea. (Academic Press, New York, 1982)

37. Portalia, N. K., Sulmartiwi, L. \& Rahardja, B. S. The growth and survival rate in lettuce aquaponic systems (Latuca sativa) of eels in various stocking densities of eel (Monopterus albus). IOP Conf. Ser. Earth Environ. Sci. 236, 012005 (2019).

38. Affandi, R., Budiardi, T., Wahju, R. I. \& Taurusman, A. A. Pemeliharaan ikan sidat dengan sistem air bersirkulasi. J. Ilmu Pertanian Indones. 18, 55-60 (2013).

39. Karipoglou, C. \& Nathanailides, C. Growth rate and feed conversion efficiency of intensively cultivated European eel (Anguilla Anguilla L.). Int. J. Fish. Aquacult. 1, 11-13 (2009).

40. Baras, E. et al. Interactions between temperature and size on the growth, size heterogeneity, mortality, and cannibalism in cultured larvae and juveniles of the Asian catfish Pangasianodon hypophthalmus (Sauvage). Aquac. Res. 42, 260-276 (2011).

41. Gracia, L. A., Rosas, V. C. \& Brito, P. R. Effects of salinity on physiological conditions in juvenile common snook Centropomus undecimalis. Comp. Biochem. Physiol. 145, 340-345 (2006).

42. Fekri, L., Affandi, R., Rahardjo, M. F., Budiardi, T., Simanjuntak, C. P. H., Fauzan, T. \& Indrayani. The effect of temperature on the physiological condition and growth performance of freshwater eel elver Anguilla bicolor bicolor (McClelland, 1844). J. Akuakultur Indones. 17, 181-190, (2018).

43. Saputra, A., Budiardi, T. \& Supriyono, E. Production performance of eel Anguilla bicolor bicolor with the addition of calcium carbonate. J. Akuakultur Indones. 15, 56-62 (2016).

44. Barton, B. A. \& Iwama, G. K. Physiological changes in fish from stress in aquaculture with emphasis on the response and effects of corticosteroids. Annu. Rev. Fish Dis. 1, 3-26 (1991).

45. Barton, B. A. Stress in finfish: past, present, and future-A historical perspective. In: Iwama, G. K., Pickering, A. D., Sumpter, J. P. \& Schreck, C. B. (Eds.) Fish stress and health in aquaculture (Cambridge University Press, Cambridge, 1997).

46. Begg, K. \& Pankhurst, N. W. Endocrine and metabolic responses to stress in a laboratory population of the tropical damselfish Acanthochromis polyacanthus. J. Fish Biol. 64, 133-145 (2004).

47. Rottmann, R. W., Floyd, R. F. \& Durborow, R. The role of stress in fish disease. SRAC Publ. 474, 4 (1992).

48. Sadler, J., Wells, R. M. G., Pankhurst, P. M. \& Pankhurst, N. W. Blood oxygen transport, rheology and hematological responses to confinement stress in diploid and triploid Atlantic salmon, Salmo salar. Aquaculture 184, 349-361 (2000).

49. Campbell, T. W. Blood biochemistry in lower vertebrates. In: 55th Annual Meeting of the American College of Veterinary Pathologists (ACVP) and 39th Annual Meeting of the American Society of Clinical Pathology (ASVCP) (Ed). (ACVP and ASVCP, Middleton WI, 2004).

50. Wagner, T. \& Congleton, J. L. Blood chemistry correlates of nutritional condition, tissue damage, and stress in migrating juvenile chinook salmon (Oncorhynchus tshawytscha). Can. J. Fish. Aquat. Sci. 61, 1066-1074 (2004).

51. Tavares-Dias, M. \& Moraes, F. R. Haematological and biochemical reference intervals for farmed channel catfish. J. Fish Biol. 71, 383-388 (2007).

52. Ajeniyi, S. A. \& Solomon, R. J. Urea and creatinine of Clarias Gariepinus in three different commercial ponds. Nat. Sci. 12, 124-138 (2014)

53. Arthanari, M. \& Dhanapalan, S. Assessment of the haematological and serum biochemical parameters of three commercially important freshwater fishes in river Cauvery Velur, Namakkal district, Tamil Nadu, India. Int. J. Fish. Aquat. Stud. 4, 155-159 (2016).

54. Fazio, F. Fish hematology analysis as an important tool of aquaculture: a review. Aquaculture 500, 237-242 (2018).

55. Rahardjo, M. F., Sjafei, D. S., Affandi, R. \& Sulistiono. Ikhtiology. (Lubuk Agung, Bandung Indonesia, 2011).

56. Siddiqui, N. Seasonal, size and comparative study of plasma proteins of four air breathing freshwater fishes. Indian Acad. Sci 85, 384-390 (1977)

57. Mlay, P. S. et al. Total plasma proteins and hemoglobin levels as affected by worm burden in freshwater fish in Morogoro, Tanzania. Livestock Res. Rural Dev. 19, 1-8 (2007).

58. Sancho, E. et al. European eel (Anguilla anguilla) plasma biochemistry alerts about propanil stress. J. Pestic. Sci. 42, 7-15 (2017).

59. Tan, C. et al. Effects of stocking density on growth, body composition, digestive enzyme levels and blood biochemical parameters of Anguilla marmorata in a recirculating aquaculture system. Turk. J. Fish. Aquat. Sci. 18, 9-16 (2018).

60. Kulkarni, R. \& Pruthviraj, C. B. Blood creatinine and some enzyme levels in four species of indian carp fishes collected from a local aquatic body. Int. Lett. Nat. Sci. 60, 13-17 (2016).

61. Gabriel, U. U. \& George, A. D. I. Plasma enzymes in Clarias gariepinus exposed to chronic levels of Roundup (glyphosate). Environ. Ecol. 23, 271-276 (2005).

62. Erlacher-Reid, C., Hoffman, W. E., Priede, M., Pulver, R. \& Tuttle, A. D. Plasma biochemistry values of recently wild-caught purple mouth moray eels (Gymnothorax vicinus). J. Zoo Wildl. Med. 42, 671-679 (2011).

63. Kulkarni, R. \& Barad, V. Haematological and blood biochemical changes in the fresh water fish, Notopterus notopterus (Pallas) exposed to acidic medium. Int. Lett. Nat. Sci. 45, 27-33 (2015).

64. Hidayaturrahmah, H. Muhamati, M. \& Santoso, H. B. Profil SGPT dan SGOT Ikan Nila (Oreochromis niloticus L.) di Sungai Riam Kanan Kalimantan Selatan. J. Pharmasci. 2, 38-46 (2015).

65. Sancho, E. et al. European eel (Anguilla anguilla) plasma biochemistry alerts about propanil stress. J. Pestic. Sci. 42(1), 7-15 (2017). 
66. Sripriya, R., Kumar, K. \& Rajendran, K. Seasonal variation of serum enzymes of Indian freshwater eel Anguila bicolor (Mcclelanand). Int. J. Fish. Aquat. Studies 3, 50-54 (2015).

67. Satheeshkumar, P., Ananthan, G., Senthilkumar, D., Khan, A. B. \& Jeevanantham, K. Comparative investigation on haematological and biochemical studies on wild marine teleost fihes from Vellar estuary, southeast coast of India. Comp. Clin. Path 21, 275-281 (2012).

68. Sahan, A., Altun, T., Çevik, F., Cengizler, i., Nevsat, E. \& Genç, E. Comparative study of some haematological parameters in European eel (Anguilla anguilla L. 1758) caught from different regions of the Ceyhan River (Adana, Turkey). J. Fish. Aquat. Sci. 24, 167-171 (2007).

69. Ponsen, S., Narkkong, N. A., Pamok, S. \& Aengwanich, W. Comparative hematological values, morphometric and morphological observation of the blood cell in captured and culture Asian eel, Monopterus albus. Am. J. Anim. Vet. Sci. 4, 32-36 (2009).

70. Sasongko, H. Effect of acute administration of eel (Anguilla bicolor bicolor) oil to hematological parameters in mice. In: Proceedings of the 1st Muhammadiyah international conference on health and pharmaceutical development (MICH-PhD 2018). (East Jakarta, Indonesia, 2018).

71. Clauss, T. M., Dove, A. D. M. \& Arnold, J. E. Hematologic disorders of fish, veterinary clinics of North America. Ex. Anim. Pract. 11, 445-462 (2008).

72. Ren, D. R. et al. A genome scan for quantitative trait loci affecting male reproductive traits in a White Duroc Chinese Erhualian resource population. J. Anim. Sci. 87, 17-23 (2008).

73. Caruso, G., Genovese, L., Maricchiolo, G. \& Modica, A. Haematological, biochemical and immunological parameters as stress indicators in Dicentrarchus labrax and Sparus aurata farmed in off-shore cages. Aquacult. Int. 13, 67-73 (2005).

74. Haenen, O. L. M., Lehmann, J., Engelsma, M. Y., Stürenberg, F. J., Roozenburg, I., Kerkhoff, S. \& Breteler, J. K. The health status of European silver eels, Anguilla anguilla, in the Dutch River Rhine Watershed and Lake IJsselmeer. Aquaculture 309, 15-24, https://doi.org/10.1016/j.aquaculture.2010.08.026 (2010).

75. Fekri, L., Affandi, R., Rahardjo, M. F., Budiardi, T. \& Simanjuntak, C. P. H. Pertumbuhan elver Anguilla bicolor McClelland, 1844 pasca pembantutan yang dipelihara di media semi alami. J. Iktiologi Indones. 19(2), 243-257 (2019).

76. Billett, H. H. Hemoglobin and hematocrit. In: Walker HK, Hall WD, Hurst JW, (ed). Clinical methods: the history, physical, and laboratory examinations. 151 p. (Butterworths, Boston, 1990).

77. Van Ginneken, V. et al. Hematology patterns of migrating European eels and the role of EVEX virus. Comp. Biochem. Physiol. C Toxicol. Pharmacol. 140, 97-102 (2005).

78. Gross, W. B. \& Siegel, H. S. Evaluation of the heterophil/lymphocyte ratio as a measure of stress in chickens. Avian Dis. 27, 972-979 (2006).

79. Boon, J. H., Cannaerts, V. M. H., Augustijn, H., Machiels, M. A. M., De Charleroy, D., \& Ollevier, F. The effect of different infection levels with infective larvae of Anguillicola crassus on haematological parameters of European eel (Anguilla anguilla). Aquaculture 87, 243-253 (1990).

80. Kurniawan, K., Prayitno, S. B., Sarjito, S., Angela, M. L. Pengaruh ekstrak daun sirsak (Annona muricata L.) terhadap profil darah dan kelulushidupan ikan lele sangkuriang (Clarias gariepinus Var. Sangkuriang) yang diinfeksi bakteri Aeromonas hydrophila. J. Aquacult. Manag. Technol. 2, 50-62 (2013).

81. Johansson-Sjobeck, M. L. \& Larsson, A. Effects of inorganic lead on delta-aminolevulinic acid dehydratase activity and haematological variables in the rainbow trout, Salmo gairdneri. Arch. Environ. Contam. Toxicol. 8, 419-431 (1979).

82. Lee, N. S., Kobayashi, J. \& Miyazaki, T. Gill filament necrosis in farmed Japanese eels, Anguilla japonica (Temminck \& Schlegel), infected with Herpesvirus anguillae. J. Fish Dis. 22, 457-463 (1999).

83. Tang, Y. et al. Acute toxicity of divalent mercury ion to Anguilla japonica from seawater and freshwater aquaculture and its effects on tissue structure. Int. J. Environ. Res. Public Health 16, 1965 (2019).

84. Caruso, G. et al. Physiological responses to starvation in the European eel (Anguilla anguilla): effects on haematological, biochemical, non-specific immune parameters and skin structures. Fish. Physiol. Biochem. 36, 71-83 (2009).

85. Molnar, P., England, P. \& Martinod, J. Mantle dynamics, uplift of the Tibetan Plateau, and the Indian Monsoon. Rev. Geophys. 31, 357 (1993).

86. Hangalapura, B., Zwart, R., Engelsma, M. \& Haenen, O. Pathogenesis of Herpesvirus anguillae (HVA) in juvenile European eel Anguilla anguilla after infection by bath immersion. Dis. Aquat. Org. 78, 13-22 (2007).

87. Capaldoa, C., Gay, F. \& Laforgia, V. Changes in the gills of the European eel (Anguilla anguilla) after chronic exposure to environmental cocaine concentration. Ecotoxicol. Environ. Saf. 169, 112-119 (2018).

88. Tsukamoto, K. \& Kuroki, M. Eels and humans. Humanity and the sea. 177 p. (Springer, Japan, 2014).

89. Shephard, K. L. Functions for fish mucus. Rev. Fish. Biol. Fish. 4, 401-429 (1994).

90. Alexander, J. B. \& Ingram, G. A. Noncellular non-specific defence mechanisms of fish. Annu. Rev. Fish. Dis. 2, 249-279 (1992).

91. Methling, C. Cardio-respiratory Physiology of the European Eel (Anguilla anguilla) in Extreme Environments. Marine Biological Section, Department of Biology PhD School of Science, Faculty of Science, Denmark: University of Copenhagen. (2015).

92. Tamam, O. A. S. The aetiology, histopathology, and ultrastructural features of perianal erythema (red anus syndrome) in the european eel (Anguilla anguilla). PLoS ONE 9(3), e90790 (2014).

93. Luo, M., Guan, R., Li, Z. \& Jin, H. The effects of water temperature on the survival, feeding, and growth of the juveniles of Anguilla marmorata and Anguilla bicolor pacifica. Aquaculture 400-401, 61-64 (2013).

94. [KKP] Kementerian Kelautan dan Perikanan. Panduan Budidaya Ikan Sidat. Jakarta, Indonesia: Pusat penyuluhan kelautan dan perikanan, KKP RI. 59 p. (2011)

95. Ritonga, $\mathrm{T}$. The response of eel fish seed Anguilla bicolor bicolor to the degree of acidity (pH) [Mini Thesis]. Bogor: Institut Pertanian. (2014).

96. Tseng, K. F. \& Wu, K. L. The ammonia removal cycle for a submerged biofilter used in a recirculating eel culture system. Aquacult. Eng. 31, 17-30 (2004).

97. Affandi, R. \& Suhenda, N. Teknik Budidaya Ikan Sidat (Anguilla bicolor bicolor). Prosiding Sumberdaya Perikanan Sidat Tropik. 47-54 (2003).

98. Herianti, I. Environmental engineering to spur development of Anguilla bicolor. J. Oseanol. Limnol. Indones. 37, 25-40 (2005).

99. Knosche, R. An effective biofilter type for eel culture in recirculating systems. Aquacult. Eng. 13, 71-82 (1994).

100. Li, D. \& Liu, S. Remote monitoring of water quality for intensive fish culture. Smart Sens. Real-Time Water Qual. Monit. Smart Sens. Meas. Instrum. 4, 217-238 (2013).

101. Yamagata, Y. \& Niwa, M. Acute and chronic toxicity of ammonia to eel Anguilla japonica. Bull. Jpn. Soc. Sci. Fish. 48, 171-176 (1982).

102. Chaudhary, R. \& Pillai, R. S. Studies on the physico-chemical parameters of Sasthamcottah lake (India) with reference to suitability for aquaculture. J. Environ. Res. Dev. 2, 402-405 (2008).

103. Wahyudi, H., Affandi, R. \& Hariyadi, S. Response of eel seed Anguilla bicolor bicolor to ammonia $\left(\mathrm{NH}_{3}\right)$ on the maintenance media [Mini Thesis]. Bogor: Institut Pertanian Bogor. (2015).

104. Takeuchi, T. Application of Recirculating Aquaculture Systems in Japan. Fisheries Science Series. (Springer, Tokyo, 2017).

105. Bregnballe, J. A. Guide to: recirculation aquaculture: an introduction to the new environmentally friendly and highly productive closed fish farming systems (Eurofish, 2015). 
106. Goddek, S., Joyce, A., Kotzen, B. \& Burnell, G. M. Aquaponics food production systems-combined aquaculture and hydroponic production technologies for the future. (Springer, 2019).

107. Chen, S., Timmons, M. B., Aneshansley, D. J. \& Bisogni, J. J. Suspended solids characteristics from recirculating aquacultural systems and design implications. Aquaculture 112, 143-155 (1993).

108. Couturier, M., Trofimencoff, T., Buil, J. U. \& Conroy, J. Solids removal at a recirculating salmon-smolt farm. Aquacult. Eng. 41, 71-77 (2009).

\section{Author contributions}

E.H. conducted the experiments and analysed the results. E.S., T.B., R.A., and Y.H. contributed to the development of the protocol and prepared the manuscript. All authors reviewed the manuscript.

\section{Competing interests}

The authors declare no competing interests.

\section{Additional information}

Correspondence and requests for materials should be addressed to E.S.

Reprints and permissions information is available at www.nature.com/reprints.

Publisher's note Springer Nature remains neutral with regard to jurisdictional claims in published maps and institutional affiliations.

Open Access This article is licensed under a Creative Commons Attribution 4.0 International License, which permits use, sharing, adaptation, distribution and reproduction in any medium or format, as long as you give appropriate credit to the original author(s) and the source, provide a link to the Creative Commons licence, and indicate if changes were made. The images or other third party material in this article are included in the article's Creative Commons licence, unless indicated otherwise in a credit line to the material. If material is not included in the article's Creative Commons licence and your intended use is not permitted by statutory regulation or exceeds the permitted use, you will need to obtain permission directly from the copyright holder. To view a copy of this licence, visit http://creativecommons.org/licenses/by/4.0/.

(C) The Author(s) 2021 